\title{
ANALISIS PENGARUH INTENSITAS MATAHARI, SUHU PERMUKAAN \& SUDUT PENGARAH TERHADAP KINERJA PANEL SURYA
}

\author{
Suwarti, Wahyono, Budhi Prasetiyo \\ Jl. Prof. H. Sudarto,SH., Tembalang, 5027, PO BOX 6199/ SMS \\ Telp. (024) 7473417, 7499585, Faks. (024)7472396 \\ http://www.polines.ac.id, e-mail: secretariat@polines.ac.id
}

\begin{abstract}
Abstrak
Tujuan utama tugas akhir ini adalah untuk mengetahui pengaruh intensitas matahari, suhu permukaan, dan sudut pengarah terhadap daya panel surya. Pengaruh intensitas matahari didapat dengan cara perubahan waktu sehingga intensitasnya bervariasi dengan sudut tetap $90^{\circ}$ dan suhu permukaan relatif sama, suhu permukaan didapatkan dengan cara memvariasi suhu dengan sudut pengarah tetap $90^{\circ}$ dan intensitas relatif sama, sudut pengarah didapat dengan cara memvariasi sudut pengarah dengan intensitas dan suhunya relatif sama. Pengaruh kinerja panel surya yaitu semakin besar intensitas matahari maka arusnya semakin besar dan tegangannya cenderung tetap. Suhhu permukaan mempengaruhi performa panel surya yaitu semakin besar temperaturenya maka tegangannya semakin kecil dan arusnya cenderung tetap. Sudut pengarah mempengaruhi performa panel surya yaitu semakin mendekati tegak lurus terhadap datangnya cahaya mathari maka tegangan dan arusnya akan semakin besar. Data-data hasil pengujian kemudian diolah untuk mengetahui daya listrik maksimum yang mampu dihasilkan. Hasil tugas akhir ini menunjukkan bahwa pada intensitas matahari $1006 \mathrm{~W} / \mathrm{m}^{2}$ dengan daya terbesar yang mampu dihasilkan adalah 28,035 watt. Pada temperature permukaan $54,5^{\circ} \mathrm{C}$ dengan daya terbesar 28,035 watt. Pada sudut pengarah $90^{\circ}$ daya terbesar yang dihasilkan adalah 26,7735 watt. Peforma panel surya dipengaruhi oleh intensitas matahari, temperatur permukaan, dan sudut pengarah semakin besar faktor yang mempengaruhinya daya yang dihasilkan juga semakin besar.
\end{abstract}

Kata kunci : Peforma panel surya, Daya yang dihasilkan, Faktor pengaruh.

\section{PENDAHULUAN}

Energi listrik telah menjadi kebutuhan primer dalam kehidupan manusia, hampir setiap sendi kehidupan manusia telah melibatkan listrik di dalamnya. Dengan semakin bertambahnya jumlah penduduk serta pertumbuhan ekonomi dan industri yang semakin pesat, mengakibatkan kebutuhan energi listrik di Indonesia juga mengalami peningkatan yang signifikan. Untuk mengatasi semakin meningkatnya kebutuhan listrik ini, perlu adanya inovasi dalam hal energi terbarukan.

Salah satu energi terbarukan yang tersedia di alam dan dapat dimanfaatkan sebagai sumber energi listrik adalah angin. Angin merupakan salah satu bentuk energi yang melimpah di bumi dan tidak ada habisnya sehingga pemanfaatan sistem konversi energi angin akan berdampak positif terhadap lingkungan. Energi angin dapat memberikan kontribusi signifikan bagi pengurangan emisi karena tidak dihasilkan emisi $\mathrm{CO}_{2}$ selama produksi energi listrik oleh turbin angin.

Untuk mengkonversikan energi angin menjadi energi listrik perlu adanya turbin angin sebagai peralatan utamanya. Turbin angin yang paling sering digunakan pada saat ini adalah turbin angin tipe horizontal (TAPH). Desain turbin angin horizontal mirip seperti kincir angin yaitu memiliki blade yang berputar pada sumbu vertikal. Jenis turbin angin poros horizontal yang memiliki unjuk kerja yang lebih baik adalah rotor sudut tipe propeller. Jenis rotor propeller dengan sudu multiblade bekerja optimum pada kecepatan angin yang relatif rendah. Kelebihan dari turbin angin poros horizontal (TAPH) adalah memiliki efisiensi yang lebih tinggi, karena sudu selalu bergerak tegak lurus terhadap angin dan menerima daya sepanjang putaran. Pemanfaatannya yang umum sekarang sudah digunakan adalah untuk memompa air dan pembangkit tenaga listrik.

Pembangkit listrik tenaga angin yang berkembang saat ini masih memiliki daya yang relatif kecil, hal tersebut dikarenakan turbin yang ada masih memiliki efisiensi yang kecil. Pada rancang bangun ini, turbin angin berjenis poros horizontal dan memiliki rotor berjumlah 3 buah, dimana pada setiap rotor memiliki 4 buah sudu yang berbentuk flat. Penggunaan rotor yang berjumlah 3 buah ini diharapkan menambah gaya dorong pada sudu turbin, sehingga akan meningkatkan putaran yang dihasilkan turbin. Dengan semakin meningkatnya putaran sudu, tentu saja akan meningkatkan efisiensi turbin angin, sehingga dapat dimanfaatkan pada PLTB. Masalah energi merupakan topik penelitian yang menarik sepanjang peradaban umat manusia. Upaya mencari sumber energi alternatif sebagai pengganti bahan bakar fosil masih tetap ramai dibicarakan. Terdapat beberapa sumber energi alam yang tersedia sebagai energi alternatif yang bersih, tidak berpolusi, aman dan dengan persediaan yang tidak terbatas (Fishbane, 1996). Salah satunya energi alternatif yang hampir mencakup kriteria aman bagi lingkungan adalah energi matahari. 
Indonesia memiliki potensi sumber energi matahari sangat besar karena mendapatkan sinar matahari sepanjang tahun.Energi matahari merupakan energi yang berjumlah sangatlah besar dan masih sangat sedikit digunakan. Jumlah rata-rata panas matahari yang dapat terpancarkan ke bumi sekitar $1 \mathrm{KW} / \mathrm{m} 2$ atau setara dengan 1000 kali konsumsi energi di seluruh dunia saat ini (Fishbane, 1996). Atau dengan kata lain, dengan menutup $0,1 \%$ saja permukaan bumi dengan solar cell yang memiliki efisiensi 10 persen sudah mampu untuk menutupi kebutuhan energi di seluruh dunia saat ini (Fishbane, 1996).

Penggunaan energi matahari tidak dapat digunakan secara langsung. Melainkan, Perlu adanya suatu alat tambahan yang dinamakan panel surya. Pada dasarnya prinsip dasar dari memanfaatkan energi matahari adalah mengkonversi dari panas matahari yang diserap oleh panel surya diubah menjadi listrik.

Dalam mengubah energi pada solar cell ada beberapa faktor yang mempengaruhi dalam pengotimalan perubahan energi. Diantaranya adalah faktor orientasi terhadap matahari yang selalu berubah-ubah yang dapat mengurangi optimalisasi solar cell dalam perubahan energi matahari menjadi energi listrik (Lorenzo, 1994). Panel surya dapat optimal ketika berhadapan langsung dengan pancaran sinar matahari, dalam artian posisi panel surya harus tegak lurus dengan cahaya yang datang (Lorenzo, 1994).

Kelemahan utama dari penggunaan energi matahari adalah energi listrik yang dihasilkan sel surya sangat dipengaruhi oleh intensitas cahaya matahari yang diterima oleh sistem, sehingga tidak dapat dijadikan sumber utama penyedia energi listrik.Permasalahaanya saat ini adalah bagaimana menggunakan panel surya untuk mendapatkan keluaran listrik yang optimal.

Pemakaian panel surya umumnya diletakkan dengan posisi tertentu dengan tanpa perubahan (Takun et al., 2011), sebagai contohnya panel surya hanya di hadapkan ke titik atas, padahal untuk mendapatkan keluaran listrik yang optimal panel diposisikan dengan sudut $90^{\circ}$ dengan matahari.

Dari kondisi normal position, efektivitas solarcell dalam menghasilkan daya yang lebih besar lebih mudah didapat (Lorenzo, 1994). Karena karakteristik dari panel surya sendiri, panel surya akan mendapatkan daya optimal ketika di posisi 90 derajat. Dengan memperhatikan perilaku bunga matahari yang selalu mengikuti arah matahari, solar cell perlu didesain seperti tersebut agar efektivitas kerja solar cell lebih maksimal (Lorenzo, 1994).

Sehingga dengan adanya alat ini berfungsi untuk menguji performa panel surya pada parameter pengaruh cuaca, temperatur dan sudut datangnya sinar matahari.

\section{LANDASAN}

\subsection{Pengertian Listrik Tenaga Surya}

Pembangkit listrik tenaga surya adalah pembangkit listrik yang mengubah energi surya menjadi energi listrik. Pembangkitan listrik bisa dilakukan dengan dua cara, yaitu secara langsung menggunakan fotovoltaik dan secara tidak langsung dengan pemusatan energi surya. Fotovoltaik mengubah secara langsung energi cahaya menjadi listrik menggunakan efek fotoelektrik (Energy Sources: Solar.Department of Energy). Pemusatan energi surya menggunakan sistem lensa atau cermin dikombinasikan dengan sistem pelacak untuk memfokuskan energi matahari ke satu titik untuk menggerakan mesin kalor.

a. Pemusatan Energi Surya

Sistem pemusatan energi surya (concentrated solar power, CSP) menggunakan lensa atau cermin dan sistem pelacak untuk memfokuskan energi matahari dari luasan area tertentu ke satu titik. Panas yang terkonsentrasikan lalu digunakan sebagai sumber panas untuk pembangkitan listrik biasa yang memanfaatkan panas untuk menggerakkan generator. Sistem cermin parabola, lensa reflektor Fresnel, dan menara surya adalah teknologi yang paling banyak digunakan. Fluida kerja yang dipanaskan bisa digunakan untuk menggerakan generator (turbin uap konvensional hingga mesin Stirling) atau menjadi media penyimpan panas.

b. Fotovoltaik

Sel surya atau sel fotovoltaik adalah alat yang mengubah energi cahaya menjadi energi listrik menggunakan efek fotoelektrik. Dibuat pertama kali pada tahun 1880 oleh Charles Fritts(Perlin, 1999). Pembangkit listrik tenaga surya tipe fotovoltaik adalah pembangkit listrik yang menggunakan perbedaan tegangan akibat efek fotoelektrik untuk menghasilkan listrik. Solar panel terdiri dari 3 lapisan, lapisan panel $\mathrm{P}$ di bagian atas, lapisan pembatas di tengah, dan lapisan panel $\mathrm{N}$ di bagian bawah. Efek fotoelektrik adalah dimana sinar

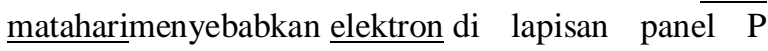
terlepas, sehingga hal ini menyebabkan proton mengalir ke lapisan panel $\mathrm{N}$ di bagian bawah dan perpindahan arus proton ini adalah arus listrik.

Pembangkit listrik tenaga surya adalah pembangkit listrik yang mengubah energi surya menjadi energi listrik. Pembangkitan listrik bisa dilakukan dengan dua cara, yaitu secara langsung menggunakan fotovoltaik dan secara tidak langsung dengan pemusatan energi surya. Fotovoltaik mengubah secara langsung energi cahaya menjadi listrik menggunakan efek fotoelektrik (Energy Sources: Solar. Department of Energy). Pemusatan energi surya menggunakan sistem lensa atau cermin dikombinasikan dengan sistem pelacak untuk memfokuskan energi matahari ke satu titik untuk menggerakan mesin kalor.

\subsection{Panel Surya}

Panel surya merupakan salah satu alat konversi energi dari energi surya menjadi energi listrik. 
Keluaran dari panel surya menghasilkan tegangan DC. Daya input dari panel surya adalah intensitas cahaya matahari $\left(\mathrm{W} / \mathrm{m}^{2}\right)$ dan luas penampang panel surya $\left(\mathrm{m}^{2}\right)$. Untuk menentukan daya input panel surya dapat digunakan rumus dari persamaan berikut:

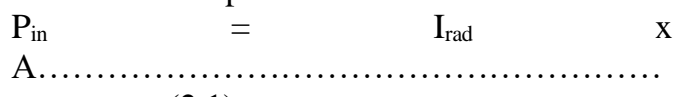

.............(2.1)

Keterangan:

$\mathrm{P}_{\mathrm{in}}=$ Daya yang masuk pada panel surya $(\mathrm{W})$

$\mathrm{I}_{\mathrm{rad}}=$ Intensitas cahaya matahari $\left(\mathrm{W} / \mathrm{m}^{2}\right)$

$\mathrm{A}=$ Luas penampang panel surya $\left(\mathrm{m}^{2}\right)$

Sedangkan output dari panel surya adalah arus dan tegangan. Untuk menentukan daya output dari panel surya digunakan rumus dari persamaan berikut:

$\begin{array}{llll}\mathrm{P}_{\text {out }} & = & \mathrm{V}_{\mathrm{PV}} & \mathrm{x} \\ \mathrm{I} & \end{array}$

Keterangan:

$\mathrm{P}_{\text {out }}$ = Daya yang keluar pada panel surya (W)

$\mathrm{V}_{\mathrm{PV}}=$ Tegangan panel surya $(\mathrm{V})$

$\mathrm{I}_{\mathrm{PV}}=$ Arus keluar panel surya (A)

Efisiensi panel surya merupakan ukuran keluaran daya listrik panel surya dibagi dengan luas penampang dan intensitas cahaya matahari. Umumnya semakin tinggi efisiensi sebuah panel surya maka semakin banyak daya yang dihasilkan panel surya. Untuk menentukan efisiensi panel surya digunakan persamaan sebagai berikut:

$$
\eta_{\text {panelsurya }}=\frac{\text { Pout }}{\text { Pin }} \times 100 \%
$$

3)

$$
\eta_{\text {panelsurya }}=\frac{V_{P V} \times I_{P V}}{I_{\text {rad }} \times A}
$$

Keterangan:

$\eta_{\text {panelsurya }}=$ Efisiensi panel surya (\%)

Jenis panel surya dikelompokan berdasarkan material sel surya yang menyusunnya. Berikut ini adalah jenis-jenis panel surya:

1. Monokristal (Mono-crystalline)

Panel surya jenis monokristal memiliki efisiensi sampai dengan 14-17\%. Kelemahan dari panel surya jenis ini adalah efisiensinya akan turun saat cuaca berawan.Berikut ini adalah contoh panel surya jenis monokristal yang ditunjukkan pada gambar 2.1.

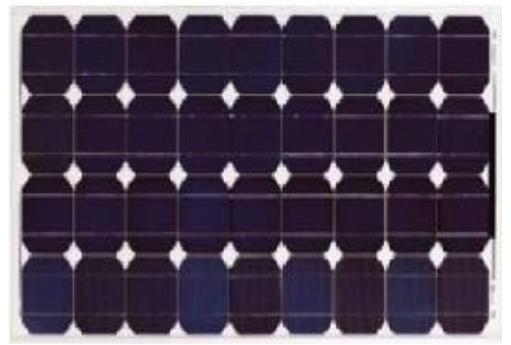

Gambar 2.1 Panel Surya Jenis Monokristal (Sumber: Modul Pengenalan Teknologi

Tenaga Surya, $2008: 32$ )

2. Polikristal (Poly-crystalline)

Merupakan panel surya yang memiliki susunan kristal acak. Tipe polikristal memerlukan luas permukaan yang lebih besar dibandingkan dengan jenis monokristal untuk menghasilkan daya listrik yang sama, akan tetapi dapat menghasilkan listrik pada saat mendung. Panelsurya bermateri polikristal dikembangkan atas alasan mahalnya materi monokristal per kilogram. Efisiensi konversi sel surya jenis polikristal berkisar antara $11,5 \%-14 \%$. Contoh panel surya jenis polikristal ditunjukkan pada gambar 2.2 berikut:

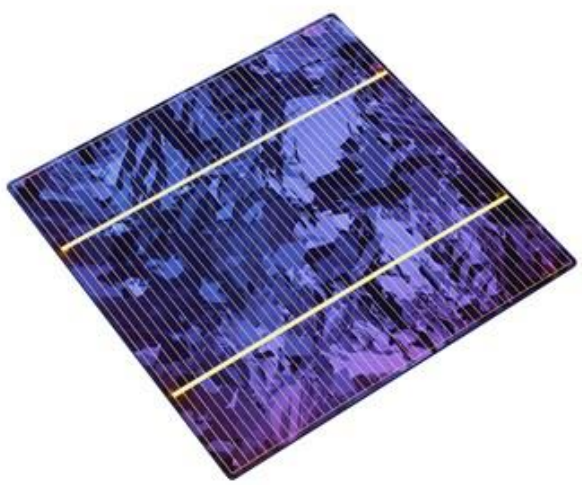

Gambar 2.2 Panel Surya Jenis Polikristal (Sumber: http://generasisolar.com/)

\section{Thin Film Solar (TFSC)}

Jenis sel surya ini diproduksi dengan cara menambahkan satu atau beberapa lapisan material sel surya yang tipis ke dalam lapisan dasar. Panel surya jenis thin film solar ditunjukkan pada gambar 2.3 berikut:

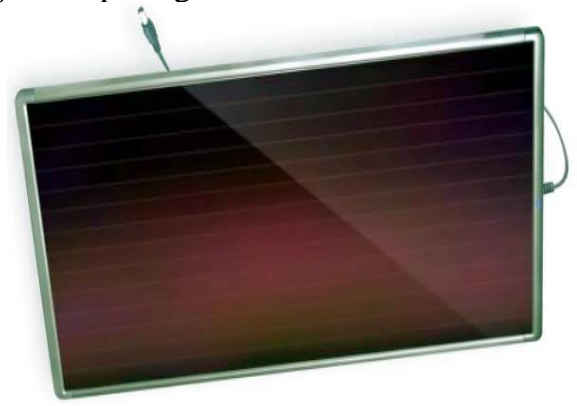

Gambar 2.3 Panel Surya Jenis Thin Film 
(Sumber:http://suryautamaputra.co.id/)

Sel surya jenis ini sangat tipis sehingga sangat ringan dan fleksibel. Jenis ini dikenal juga dengan nama TFPV (Thin Film Photovoltaic). Berdasarkan materialnya, sel surya thin film ini digolongkan menjadi:
a. Amorphous Thin-Film Silicon (a-Si) Solar Cells.
b. Cadmium Telluride (CdTe) Solar Cells.
c. Copper Indium Gallium Selenide (CIGS) Solar Cells.

\section{Material Lain}

Panel surya pada generasi ketiga tersusun atas lebih banyak variasi material untuk masing-masing panel surya. Beberapa diantaranya jenis-jenis panel surya tersebut adalah:
a. Copper zinc tin sulfide solar cell (CZTS)
b. Dye sensitized solar cell
c. Organic solar cell
d. Perovskite solar cell
e. Polymer solar cell
f. Quantum dot solar cell
g. Building integrated photovoltaics (BIPV)

Dari Gambar 2.6 dapat dilihat ketika cahaya matahari yang diterima solar cell dalam berbagai posisi mulai dari $0^{\circ}-90^{\circ}$. Solar cell menghasilkan daya maksimal ketika posisinya saling tegak lurus dengan cahaya matahari. Dengan memperhatikan perilaku bunga matahari yang selalu mengikuti arah matahari, solar cell perlu didesain seperti tersebut agar efektivitas kerja solar cell lebih maksimal (Lorenzo, 1994).

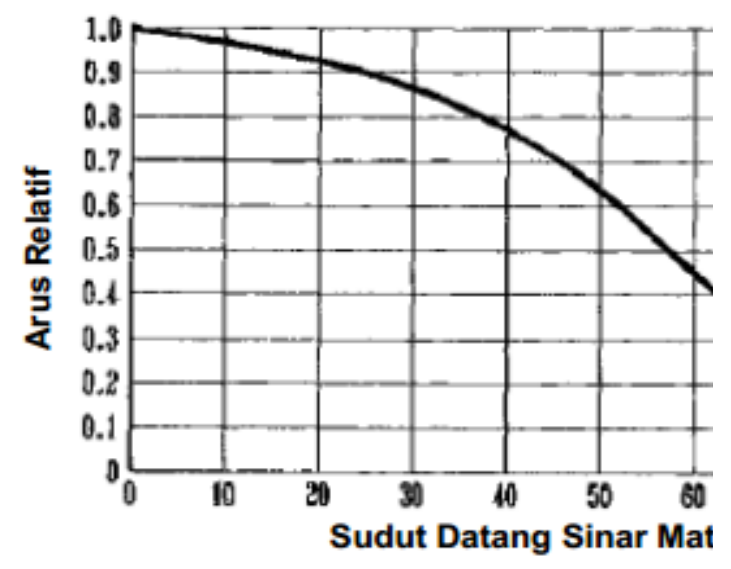

Gambar 2.6. Kurva pada Solar Cell dengan sudut tangkap antara $0^{\circ}-90^{\circ}$ (Lorenzo, 1994)

\subsection{Posisi Letak Sel Surya terhadap Matahari}

Mempertahankan sinar matahari jatuh ke sebuah permukaan modul surya secara tegak lurus akan memperoleh energi maksimum $\pm 1000 \mathrm{w} / \mathrm{m} 2$ atau $1 \mathrm{kw} / \mathrm{m} 2$. Untuk mempertahankan tegak lurusnya sinar matahari terhadap panel surya dibutuhkan pengaturan posisi modul surya, karena sun altitude akan berubah setiap jam dalam sehari.

\subsection{Mitrokontroler}

Mikrokontroler adalah sebuah chip yang berfungsi sebagai pengontrol rangkaian elektronik dan umumnya dapat menyimpan program di dalamnya terdiri dari CPU (Central Processing Unit), memori I/O dan unit pendukung seperti analog-to-Digital Converter (ADC) yang sudah terintegerasi di dalamnya.

Kelebihan sistem dengan mikrokontroler yaitu:

1. Penggerak mikrokontoler memakai bahasa pemograman assembly dengan berpatokan pada kaidah digital dasar sehingga pengoperasian sistem menjadi sangat mudah dikerjakan sesuai dengan logika sistem.

2. Mikrokontroler tersusun dalam satu chip dimana prosesor, memori dan I/O terintegrasi menjadi satu kesatuan kontrol sistem sehingga mikrokontroler dapat dikatakan sebagai komputer mini yang dapat bekerja secara inovatif sesuai dengan kebutuhan sistem.

3. Sistem running bersifat berdiri sendiri tanpa tergantung dengan komputer sedangkan parameter komputer hanya digunakan untuk download perintah instruksi atau program.

4. Tersedia fasilitas tambahan untuk pengembangan memori dan $\mathrm{I} / \mathrm{O}$ yang disesuaikan dengan kebutuhan sistem.

Karakteristik Mikrokontroler yaitu:

1. Memiliki program khusus yang disimpan dalam memori untuk aplikasi tertentu tidak seperti PC yang multifungsi, program mikrokontroler ini relatif lebih kecil daripada program di PC.

2. Rangkaiannya sederhana dan kompak.

3. Harga murah dikarenakan komponennya sedikit.

4. Unit I/O sederhana, misalnya LCD, LED dan Latch.

5. Lebih tahan terhadap kondisi lingkungan ekstrim.

\subsection{Arduino Uno R3}

Arduino Uno R3 adalah papan pengembangan (development board) mikrokontroler yang berbasis chip ATmega328P. Disebut sebagai papan pengembangan karena board ini memang berfungsi sebagai arena prototyping sirkuit mikrokontroller. Dengan menggunakan papan pengembangan, akan lebih mudah merangkai rangkaian elektronika mikrokontroller dibanding jika memulai merakit ATMega328 dari awal di breadboard. Board arduino uno tampak depan dapat dilihat pada gambar 2.7 


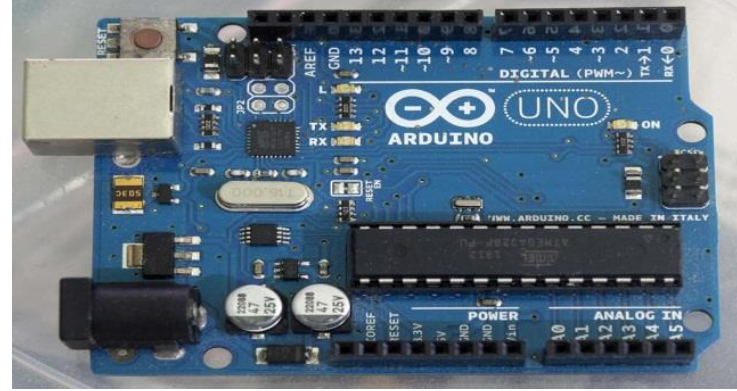

Gambar 2.7. Board Arduino Uno R3 Tampak Depan (Sumber : http://ecadio.com/mengenal-dan-belajararduino-uno-r3)

Arduino Uno memiliki 14 digital pin input / output (atau biasa ditulis $\mathrm{I} / \mathrm{O}$, dimana 6 pin diantaranya dapat digunakan sebagai output PWM), 6 pin input analog, menggunakan crystal $16 \mathrm{MHz}$, koneksi USB, jack listrik, header ICSP dan tombol reset. Hal tersebut adalah semua yang diperlukan untuk mendukung sebuah rangkaian mikrokontroler. Cukup dengan menghubungkannya ke komputer dengan kabel USB atau diberi power dengan adaptor AC-DC atau baterai, sudah dapat bermain-main dengan Arduino UNO tanpa khawatir akan melakukan sesuatu yang salah. Kemungkinan paling buruk hanyalah kerusakan pada chip ATMega328, yang dapat diganti sendiri dengan mudah dan dengan harga yang relatif murah.

Kata " Uno " berasal dari bahasa Italia yang berarti "satu", dan dipilih untuk menandai peluncuran Software Arduino (IDE) versi 1.0. Arduino. Sejak awal peluncuran hingga sekarang, Uno telah berkembang menjadi versi Revisi 3 atau biasa ditulis REV 3 atau R3. Software Arduino IDE, yang bisa diinstall di Windows maupun Mac dan Linux, berfungsi sebagai software yang membantu anda memasukkan (upload) program ke chip ATMega328 dengan mudah. Spesifikasi arduino dapat dilihat pada tabel 2.1 .

Tabel 2.1 Spesifikasi Arduino Uno R3

\begin{tabular}{|l|l|}
\hline Chip mikrokontroller & ATmega328P \\
\hline Tegangan operasi & $5 \mathrm{~V}$ \\
\hline $\begin{array}{l}\text { Tegangan input (yang direkomendasikan, via jack } \\
\text { DC) }\end{array}$ & $6 \mathrm{~V}-12 \mathrm{~V}$ \\
\hline Tegangan input (limit, via jack DC) & $6 \mathrm{~V}-20 \mathrm{~V}$ \\
\hline Digital I/O pin & 14 buah, 6 diantaranya menyediakan PWM \\
\hline Analog Input pin & 6 buah \\
\hline Arus DC per pin I/O & $20 \mathrm{~mA}$ \\
\hline Arus DC pin 3.3V & $50 \mathrm{~mA}$ \\
\hline Memori Flash & $32 \mathrm{~KB}, 0.5 \quad \mathrm{~KB}$ telah digunakan untuk \\
\hline SRAM & bootloader \\
\hline EEPROM & $2 \mathrm{~KB}$ \\
\hline Clock speed & $1 \mathrm{~KB}$ \\
\hline Dimensi & $16 \mathrm{Mhz}$ \\
\hline Berat & $68.6 \mathrm{~mm} \times 53.4 \mathrm{~mm}$ \\
\hline
\end{tabular}

\subsubsection{Pemograman}

Pemrograman board Arduino dilakukan dengan menggunakan Arduino Software (IDE), Chip ATmega328 yang terdapat pada Arduino Uno R3 telah diisi program awal yang sering disebut bootloader. Bootloader tersebut yang bertugas untuk memudahkan anda melakukan pemrograman lebih sederhana menggunakan Arduino Software, tanpa harus menggunakan tambahan hardware lain. Cukup hubungkan Arduino dengan kabel USB ke PC atau Mac/Linux anda, jalankan software Arduino Software (IDE), dan anda sudah bisa mulai memrogram chip ATmega328. Lebih mudah lagi, di dalam Arduino Software sudah diberikan banyak contoh program yang memanjakan anda dalam belajar mikrokontroller. Gambar 2.8 adalah salah satu contoh halaman pemograman. 


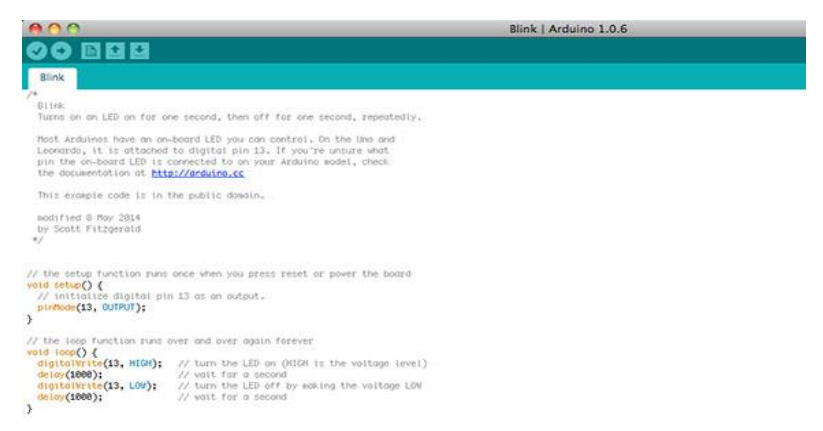

Gambar 2.8 Pemograman

Sumber: ( http://ecadio.com/mengenaldan-belajar-arduino-uno-r3)

Untuk pengguna mikrokontroller yang sudah lebih mahir, anda dapat tidak menggunakan bootloader dan melakukan pemrograman langsung via header ICSP (In Circuit Serial Programming) dengan menggunakan Arduino ISP

Arduino Uno R3 telah dilengkapi dengan chip ATmega16U2 yang telah diprogram sebagai konverter USB to Serial. Firmware ATmega16U2 di load oleh DFU bootloader, dan untuk merubahnya anda dapat menggunakan software Atmel Flip (Windows)atau DFU programmer(Mac OSX dan Linux), atau menggunakan header ISP dengan menggunakan hardware external programmer.

\subsubsection{Input dan Output}

c. digunakan untuk mengaktifkan

d. interrups. Gunakan fungsi attachInterrupt

e. PWM: Pin 3, 5, 6, 9, 10, dan 11 menyediakan output PWM 8-bit dengan menggunakan fungsi analogWrite

f. SPI : Pin 10 (SS), 11 (MOSI), 12 (MISO), dan 13 (SCK) mendukung komunikasi SPI dengan menggunakan SPI Library

g. LED : Pin 13. Pada pin 13 terhubung built-in led yang dikendalikan oleh digital pin no 13

h. TWI : Pin A4 (SDA) dan pin A5 (SCL) yang mendukung komunikasi TWI dengan menggunakan Wire Library

c. mikrokontroller. Sama dengan

d. penggunaan tombol reset yang tersedia.

\subsubsection{Komunikasi}

Arduino Uno R3 memiliki beberapa fasilitas untuk berkomunikasi dengan komputer, berkomunikasi dengan Arduino lainnya, atau dengan mikrokontroller lain nya. Chip Atmega328 menyediakan komunikasi serial UART TTL (5V) yang tersedia di pin $0(\mathrm{RX})$ dan pin 1 (TX). Chip ATmega16U2 yang terdapat pada board berfungsi
Seperti yang telah disebutkan sebelumnya, Arduino Uno memiliki 14 buah digital pin yang dapat digunakan sebagai input atau output, dengan menggunakan fungsi pinMode, digital Write, dan digital. Pin-pin tersebut bekerja pada tegangan 5V, dan setiap pin dapat menyediakan atau menerima arus $20 \mathrm{~mA}$, dan memiliki tahanan pull-up sekitar 20-50k ohm (secara default dalam posisi disconnect). Nilai maximum adalah 40mA, yang sebisa mungkin dihindari untuk menghindari kerusakan chip mikrokontroller

Beberapa pin memiliki fungsi khusus :

a. Serial, terdiri dari 2 pin : pin $0(\mathrm{RX})$ dan pin 1 (TX) yang digunakan untuk menerima (RX) dan mengirim (TX) data serial

b. External Interrups, yaitu pin 2 dan pin 3. Kedua pin tersebut dapat

Arduino Uno memiliki 6 buah input analog, yang diberi tanda dengan A0, A1, A2, A3, A4, A5. Masing-masing pin analog tersebut memiliki resolusi 10 bits (jadi bisa memiliki 1024 nilai). Secara default, pin-pin tersebut diukur dari ground ke $5 \mathrm{~V}$, namun bisa juga menggunakan pin AREF dengan menggunakan fungsi analogReference.

Beberapa in lainnya pada board ini adalah :

a. AREF. Sebagai referensi tegangan untuk input analog.

b. Reset. Hubungkan ke LOW untuk melakukan reset terhadap

menterjemahkan bentuk komunikasi ini melalui USB dan akan tampil sebagai Virtual Port di komputer. Firmware 16U2 menggunakan driver USB standar sehingga tidak membutuhkan driver tambahan.

Pada Arduino Software (IDE) terdapat monitor serial yang memudahkan data textual untuk dikirim menuju Arduino atau keluar dari Arduino. Led TX dan RX akan menyala berkedip-kedip ketika ada data yang ditransmisikan melalui chip USB to Serial via 
kabel USB ke komputer. Untuk menggunakan komunikasi serial dari digital pin, gunakan SoftwareSerial library

Chip ATmega328 juga mendukung komunikasi I2C (TWI) dan SPI. Di dalam Arduino Software (IDE) sudah termasuk Wire Library untuk memudahkan anda menggunakan bus I2C. Untuk menggunakan komunikasi SPI, gunakan SPI library

\subsubsection{Reset Otomatis}

Biasanya, ketika anda melakukan pemrograman mikrokontroller, anda harus menekan tombol reset sesaat sebelum melakukan upload program. Pada Arduino Uno, hal ini tidak lagi merepotkan anda. Arduino Uno telah dilengkapi dengan auto reset yang dikendalikan oleh software pada komputer yang terkoneksi. Salah satu jalur flow control (DTR) dari ATmega16U pada Arduino Uno R3 terhubung dengan jalur reset pada ATmega328 melalui sebuah kapasitor $100 \mathrm{nF}$. Ketika jalur tersebut diberi nilai LOW, mikrokontroller akan di reset. Dengan demikian proses upload akan jauh lebih mudah dan anda tidak harus menekan tombol reset pada saat yang tepat seperti biasanya.

\subsection{Data Logger}

Data logger adalah sebuah program untuk melakukan data logging dengan menggunakan modul mikro SD yang dihubungkan ke mikrokontroler. Data logging adalah proses pengumpulan dan perekaman data secara otomatis dari sensor dengan tujuan pengarsipan atau analisis. Bentuk fisik dari data logger yaitu kecil, portabel dan dilengkapi dengan mikroprosesor serta memori internal + eksternal untuk menyimpan data berupa sensor.

Data logger berbasis mikrokontroler untuk mengumpulkan data melalui sensor yang akan dianalisis dan ditampilkan hasilnya. Sensor yang dimaksudkan disini untuk mengkonversi besaran fisik menjadi sinyal listrik yang diukur secara kemudian dikirim ke mikrokontroler untuk diolah.

\section{8}

\section{Sensor}

Sensor adalah jenis tranduser yang mengubah besaran mekanis, magnetis, panas, sinar dan kimia menjadi tegangan dan arus lstrik. Sensor yang akan dibahas ini meliputi:

1. Sensor Tegangan

Sensor tegangan adalah alat yang dapat mengukur dan membaca nilai tegangan suatu rangkaian elektronika, umumnya berupa rangkaian pembagi tegangan atau voltage divider. Tegangan di baterai akan dikonversikan ke dalam teganagn yang dapat dibaca pada mikrokontroler sebesar 0-5 Volt.

\section{Sensor Arus}

Sensor arus adalah alat yang dapat mendeteksi arus listrik (AC atau DC) dan mampu menghasilkan sinyal yang sebanding. Sinyal yang dihasilkan berupa tegangan analog dan atau tegangan digital.

\section{HASIL DAN ANALISA}

Dari tabel 4.1 dan lampiran 1 dapat dibuat grafik arus fungsi tegangan pada intensitas matahari yang berbeda sebagaimana gambar 4.1

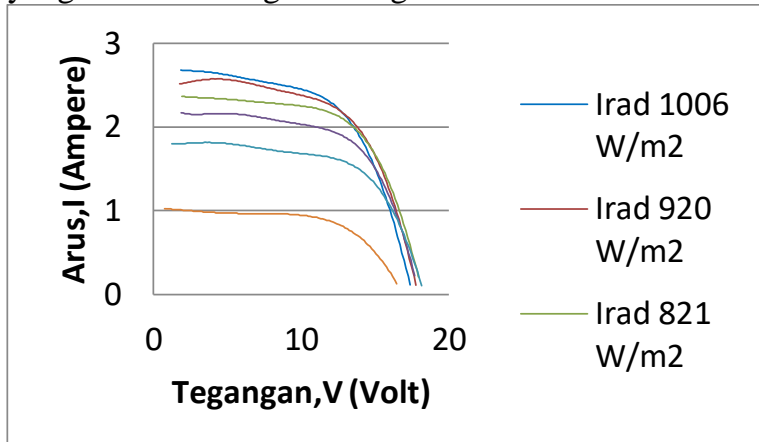

\section{Gambar 4.1 Grafik hubungan Arus (I) dengan}

Tegangan (V) pada intensitas matahari

Berdasarkan gambar 4.1 pada masing-masing intensitas matahari, pada saat tegangan semakin besar maka arusnya akan semakin naik hingga mencapai titik puncak, selanjutnya dengan bertambahnya tegangan arus semakin menurun. Arus maksimal pada intensitas $1006 \mathrm{~W} / \mathrm{m}^{2}$ didapat 2,7A dan tegangan maksimalnya $17,38 \mathrm{~V}$, arus pada intensitas $920 \mathrm{~W} / \mathrm{m}^{2}$ didapat 2,62A dan tegangan maksimalnya $17,77 \mathrm{~V}$, arus pada intensitas $821 \mathrm{~W} / \mathrm{m}^{2}$ didapat $2,45 \mathrm{~A}$ dan tegangan maksimalnya $17,94 \mathrm{~V}$, arus pada intensitas $747 \mathrm{~W} / \mathrm{m}^{2}$ didapat $2,25 \mathrm{~A}$ dan tegangan maksimalnya $17,69 \mathrm{~V}$, arus pada intensitas $613 \mathrm{~W} / \mathrm{m}^{2}$ didapat $1,85 \mathrm{~A}$ dan tegangan maksimalnya $18,16 \mathrm{~V}$, dan arus pada inensitas $541 \mathrm{~W} / \mathrm{m}^{2}$ didapat $1,05 \mathrm{~A}$ dan tegangan maksimalnya $16,47 \mathrm{~V}$.

Dari tabel 4.1 dan lampiran 1 dapat dibuat grafik daya fungsi tegangan pada intensitas matahari yang berbeda sebagaimana gambar 4.2

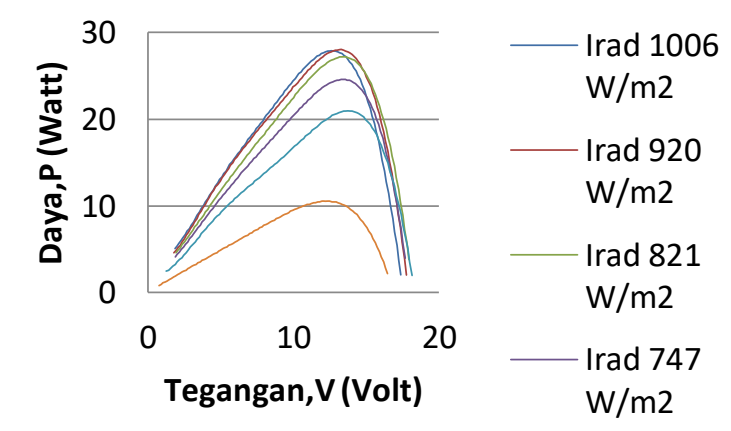

Gambar 4.2 Gafik Hubungan Daya (P) dengan Tegangan $(\mathrm{V})$ pada intensitas matahari

Berdasarkan gambar 4.2 pada masing-masing intensitas matahari, pada saat tegangan semakin besar maka dayanya akan semakin naik hingga mencapai titik puncak, selanjutnya dengan bertambahnya tegangan daya semakin menurun. Daya maksimal pada intensitas $1006 \mathrm{~W} / \mathrm{m}^{2}$ didapat $27,478 \mathrm{~W}$ dan tegangan maksimalnya $17,38 \mathrm{~V}$, daya maksimal pada intensitas $920 \mathrm{~W} / \mathrm{m}^{2}$ didapat $28,035 \mathrm{~W}$ dan tegangan maksimalnya $17,77 \mathrm{~V}$, daya maksimal pada intensitas $821 \mathrm{~W} / \mathrm{m}^{2}$ didapat $27,306 \mathrm{~W}$ dan tegangan maksimalnya $17,24 \mathrm{~V}$, daya maksimal pada intensitas 
$747 \mathrm{~W} / \mathrm{m}^{2}$ didapat $25,271 \mathrm{~W}$ dan tegangan maksimalnya $17,69 \mathrm{~V}$, daya maksimal pada intensitas $613 \mathrm{~W} / \mathrm{m}^{2}$ didapat $21,054 \mathrm{~W}$ dan tegangan maksimalnya $18,16 \mathrm{~V}$, dan daya maksimal pada intensitas $541 \mathrm{~W} / \mathrm{m}^{2}$ didapat $11,16 \mathrm{~W}$ dan tegangan maksimalnya $16,47 \mathrm{~V}$.

Dari tabel 4.2 dan lampiran 2 dapat dibuat grafik arus fungsi tegangan pada suhu permukaan yang berbeda sebagaimana gambar 4.3

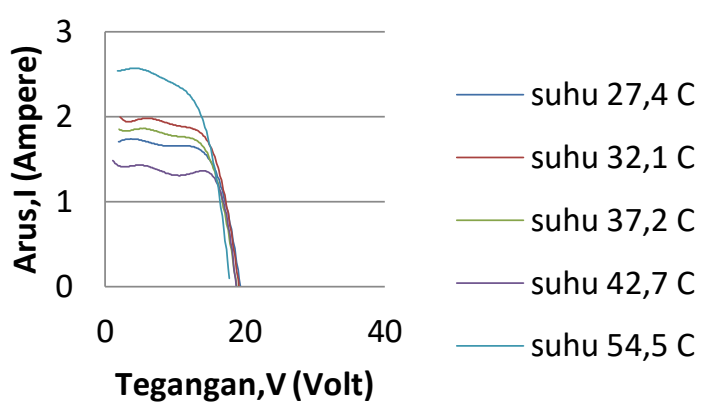

Gambar 4.3 Grafik Hubungan Arus (I) dengan Tegangan $(V)$ pada suhu permukaan

Berdasarkan gambar 4.3 pada masing-masing suhu permukaan, pada saat tegangan semakin besar maka arusnya akan semakin naik hingga mencapai titik puncak, selanjutnya dengan bertambahnya tegangan arus semakin menurun. Arus maksimal pada suhu $27,4^{\circ} \mathrm{C}$ didapat $1,8 \mathrm{~A}$ dan tegangan maksimalnya $19,35 \mathrm{~V}$, arus pada suhu $32,1^{\circ} \mathrm{C}$ didapat $2 \mathrm{~A}$ dan tegangan maksimalnya $19,16 \mathrm{~V}$, arus pada suhu $37,2^{\circ} \mathrm{C}$ didapat $1,95 \mathrm{~A}$ dan tegangan maksimalnya $18,82 \mathrm{~V}$, arus pada suhu $42,7^{\circ} \mathrm{C}$ didapat $1,9 \mathrm{~A}$ dan tegangan maksimalnya $18,26 \mathrm{~V}$, dan arus pada suhu $54,5^{\circ} \mathrm{C}$ didapat $2,65 \mathrm{~A}$ dan tegangan maksimalnya $17,72 \mathrm{~V}$.

Dari tabel 4.2 dan lampiran 2 dapat dibuat grafik daya fungsi tegangan pada suhu permukaan yang berbeda sebagaimana gambar 4.4
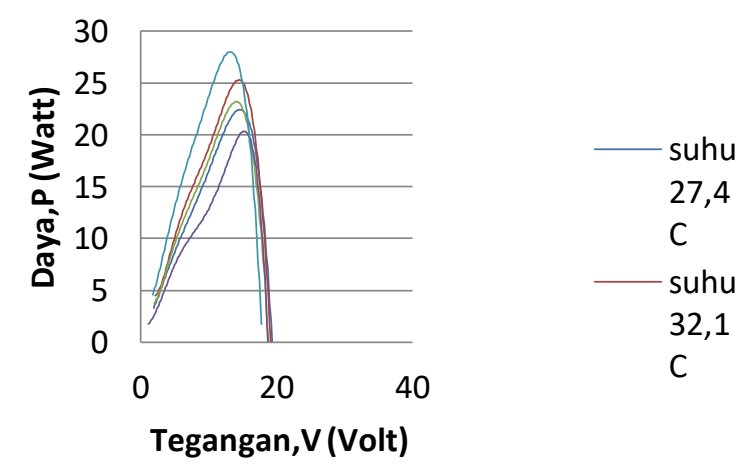

\footnotetext{
Gambar 4.4 Grafik Hubungan Daya (P) dengan

Tegangan (V) pada suhu permukaan

Berdasarkan gambar 4.4 pada masing-masing suhu permukaan, pada saat tegangan semakin besar
}

maka dayanya akan semakin naik hingga mencapai titik puncak, selanjutnya dengan bertambahnya tegangan daya semakin menurun. Daya maksimal pada suhu $27,4^{\circ} \mathrm{C}$ didapat $22,1415 \mathrm{~W}$ dan tegangan maksimalnya $19,35 \mathrm{~V}$, daya maksimal pada suhu $32,1^{\circ} \mathrm{C}$ didapat $25,038 \mathrm{~W}$ dan tegangan maksimalnya $19,16 \mathrm{~V}$, daya maksimal pada suhu $37,2^{\circ} \mathrm{C}$ didapat $23,273 \mathrm{~W}$ dan tegangan maksimalnya $18,82 \mathrm{~V}$, daya maksimal pada suhu $42,7^{\circ} \mathrm{C}$ didapat $26,012 \mathrm{~W}$ dan tegangan maksimalnya $18,26 \mathrm{~V}$, dan daya maksimal pada suhu $54,5^{\circ} \mathrm{C}$ didapat $28,035 \mathrm{~W}$ dan tegangan maksimalnya $17,77 \mathrm{~V}$.

\section{KESIMPULAN}

Pada pengujian pengaruh intensitas matahari, suhu permukaan, dan sudut pengarah terhadap daya panel surya dapat diketahui bahwa :

1. Semakin besar intensitas matahari maka arus yang dihasilkan akan semakin besar dan tegangannya cenderung tetap, selain itu semakin besar intensitas matahari maka daya yang dihasilkan juga semakin besar.

2. Semakin besar suhu permukaannya maka tegangan yang dihasilkan akan semakin kecil dan arusnya cenderung tetap, selain itu semakin besar temperature permukaan maka dayanya semakin besar.

3. Semakin mendekati tegak lurus terhadap datangnya cahaya mathari maka tegangan dan arusnya akan semakin besar, selain itu semakin mendekati tegak lurus sudut pengarah mendekati cahaya matahari maka semakin besar dayanya.

\section{DAFTAR PUSTAKA}

Fishbane, P.M., Gasirowicz, S., and Thornton, S.T., 1996: Physics for scientists and engineers, 2nd edition, Prentice-hall, New Jersey

Lorenzo, Eduardo. 1994. Solar electricity, engineering of photovoltaic systems. Madrid: Polytechnic University of Madrid

Takun, Pongsakor, Somyot Kaitwanidvilai, Chaiyan Jettanasen, Maximum power point tracking using fuzzy logic control for photovoltaic. Hongkong http://ecadio.com/mengenal-dan-belajar-arduino-unor3 (23 Agustus 2018)

http://armand10dma.blogspot.com/2011/08/panelsurya.html\#more(20 Agustus 2018) 